\title{
HUMAN RIGHTS, INEQUALITY AND PUBLIC INTEREST LITIGATION: A CASE STUDY ON SANITATION FROM BRAZIL
}

Ana Paula Barcellos

Professora de Direito Constitucional. Departamento de Direito do Estado, Universidade do Estado do Rio de Janeiro, Brazil. anapauladebarcellos@gmail.com

Ricardo Faé de Moura

Faculty of Medical Sciences. Santa Casa of São Paulo, Brazil

Marcia C. Castro

Associate Professor. Department of Global Health and Population. Harvard T.H. Chan School of Public Health, USA.

Received: 2016-05-22. Accepted: 2016-08-12.

\begin{abstract}
Disaggregated data on the relative success of the UN millennium goals made clear that the progress achieved in many countries, Brazil included, was not equitable, positioning the question "How to address inequalities?" as the next pressing challenge in human rights. Public law litigation could be regarded as a tool to reduce inequality, particularly in Brazil, given a unique institution of its legal system, the Public Prosecutors Office. This paper uses public interest litigation discussing access to sanitation services to test this hypothesis. In 2013 , only $58.2 \%$ of the households had access to sanitation, with significant regional inequality in coverage. Boolean analysis was applied to assess court orders (2003-2013) and results showed a disconnect between litigation and demand for sanitation, indicating that areas that were better off in various social and economic indicators were the ones receiving attention. The paper suggests reflections on how public interest litigation could target those most in need.
\end{abstract}

Keywords: Human rights - Access to sanitation - Public interest litigation 


\section{INTRODUCTION}

The UN millennium goals were able to concentrate efforts to enhance access to human rights over the globe. Access to basic sanitation was one of these goals, described modestly as access to improved sanitation facilities (in contrast with open defecation practices). Progress was made, no doubt. However, as disaggregated data become available, it is clear that progress was not even, and in some occasions worsened inequalities were observed. ${ }^{1}$

Public law litigation could be a tool to help reduce inequalities in access to rights. Public interest litigators could focus their attention on the most in need, leading Courts and defendants in charge of providing for these rights to pay attention to these specific populations. This hypothesis would seem even more appealing in Brazil, where there is this unique institution in charge of pursuing public interest through litigation, although not exclusively: the Public Attorney's Office.

The data collected and discussed in this paper on cases addressing access to sanitation services in Brazil do not confirm this hypothesis, though. It seems that the way Public Attorneys organize their work according to a complaint-reacting logic, as most public interest litigators do around the world, prevents them to reach the most excluded and disenfranchised. The paper suggests reflections on how public interest litigation could target those most in need.

\section{HUMAN RIGHTS INEQUALITY IN BRAZIL: A GLIMPSE}

Regional inequality in Brazil regarding access to services connected to rights, as well as social and health outcomes, has been widely recognized. The South and Southeast regions regularly have better outcomes, while the North and Northeast regions often lag behind. ${ }^{2}$ According to data from 2010 Population Census, the North and Northeast regions concentrated $36.22 \%$ of Brazilian population, $73 \%$ in urban areas, but only $18.8 \%$ of the GDP. These regions often observe lower socioeconomic status, higher mortality and fertility, and low access to health services. While recent improvements have been

1 United Nations (2015) The Millennium Development Goals Report. New York: United Nations.

2 Hoffmann R (2000) Mensuração da desigualdade e da pobreza no Brasil. In: Henriques R, editor. Desigualdade e pobreza no Brasil. Rio de Janeiro: IPEA. pp. 81-107. Medici AC, Agune AC (1994) Desigualdades sociais e desenvolvimento no Brasil: uma análise dos anos 80 ao nível regional. Ensaios, FEE, Porto Alegre 15: 458-488. Rocha S (1998) Desigualdade Regional e Pobreza no Brasil: A Evolução - 198/95 - Texto para discussão n 567 . Rio de Janeiro: IPEA. 
observed $^{3}$ major regional inequalities still persist in the country. ${ }^{4}$

In 2010 the deficit in sanitation services for the North and Northeast regions was, respectively, $86.0 \%$ and $66.0 \%$, while in the Southeast region the deficit was $18.9 \%{ }^{5}$. Disparities between urban and rural areas also exist. In 2013, 67.1\% of the urban households in Brazil had access to sanitation; in rural areas the coverage was only $4.6 \%$. Further, $90.8 \%$ of urban households in the Southeast region had access to sanitation, against only $18.2 \%$ in the North region; rural households in those regions had coverage of $13.7 \%$ and $0.6 \%$, respectively.

Others indicators describe the same picture ${ }^{6}$. Although infant mortality rates in Brazil dropped from 29 to 15 between years 2000 and 2013, regional inequalities still persist. In 2013, the infant mortality rate for both the North and Northeast regions was 19,2, while in the South region it was only 10,4. Inequalities in access to other rights, such as education, also exist. In the Southeast Region, $85 \%$ of the children ages four and five attended school in 2013; in the North Region this figure amounted to only $67,9 \%$. Age-grade distortion is also more frequent in the North and Northeast Regions (55,2\% e 52,2\%, respectively).

Inequality can be framed from other perspectives, as race and wealthy. From 1999-2002, infant mortality in black children was 30\% to $80 \%$ higher than that of white children, and disparities could be even larger depending on the scale of analysis and the level of underreporting ${ }^{7}$. School attendance has improved in the last years in Brazil. However, according to 2013 data, though $93,1 \%$ of children ages four and five from the wealthiest quintile attended school, the figure was $75,2 \%$ for the poorest quintile, and age-grade distortion in the poorest quintile was 3,3 times that of the wealthiest quintile.

Notwithstanding the importance of other perspectives in inequality, in this paper we approach inequality in access to sanitation services using a regional/spatial framework combined with the Human Development Index (HDI) for municipalities as a social-economic indicator. Although disparities in sanitation access also exist at much

3 Castro MC (2009) Spatio-temporal trends of infant mortality in Brazil. XXVI IUSSP International Population Conference. Marrakech, Morocco.

4 IPEA (2012) Políticas sociais: acompanhamento e análise. Brasília Instituto de Pesquisa Econômica Aplicada, Diretoria de Estudos e Políticas Sociais.

5 Saiani CCS, Galvão GC (2011) Evolução das Desigualdades Regionais do Déficit de Acesso a Serviços de Saneamento Básico no Brasil: Evidências de um Incentivo Adverso dos Objetivos de Desenvolvimento do Milênio? $39^{\circ}$ Encontro Nacional de Economia Foz do Iguaçu, Paraná: ANPEC.

6 IBGE (2014) Síntese de Indicadores Sociais. Uma análise das condições de vida da população brasileira. Rio de Janeiro: Instituto Brasileiro de Geografia e Estatística - IBGE.

7 Cardoso AM, Santos RV, Coimbra Jr. CEA (2005) Mortalidade infantil segundo raça/cor no Brasil: o que dizem os sistemas nacionais de informação? Cadernos de Saude Publica 21: 1602-1608. 
finer scales (e.g., neighborhoods within cities), such detailed data are not available for the entire country.

This glimpse on Brazilian inequality illustrates that although public policies have achieved important progress on human rights access in Brazil in the last decades, this progress has not removed the inequalities that exist in the country. Could public interest litigation help change this pattern through targeted interventions?

This paper will focus on the right to sanitation as a case study, trying to assess how public interest litigation could help address inequalities. The next topic discusses why sanitation is a good case for this kind of endeavor.

\section{Human Right to Sanitation: the Brazilian Case}

"Sanitation is a cornerstone of public health" said the World Health Organization (WHO) Director-General Dr. Margaret Chan. Access to proper sanitation improves human health and well-being and contributes to reductions in the burden of diseases such as diarrhea, cholera, schistosomiasis, and trachoma, especially among children ${ }^{8}$. Combined, proper access to water, sanitation and hygiene could prevent at least $9.1 \%$ of the global disease burden and $6.3 \%$ of all deaths ${ }^{9}$. There is international consensus that promoting equitable access to basic sanitation services would reduce child mortality, improve overall health and education outcomes, reduce poverty, and contribute to sustainable development ${ }^{10}$.

Moreover, access to both water and sanitation was explicitly recognized as a human right by the United Nations in $2010^{11}$. Yet, access to sanitation is inequitably distributed and an estimated 2.5 billion people worldwide lack access to basic sanitation. ${ }^{12}$

The Millennium Development Goal (MDG) 7, target C, set the aim to halve the proportion of people without sustainable access to safe drinking water and basic sanitation by $2015^{13}$. In 2010, UNICEF stated

8 Fewtrell L, Kaufmann RB, Kay D, Enanoria W, Haller L, et al. (2005) Water, sanitation, and hygiene interventions to reduce diarrhoea in less developed countries: a systematic review and meta-analysis. The Lancet Infectious Diseases 5: 42-52. Montgomery M, Elimelech M (2007) Water and Sanitation in Developing Countries: Including Health in the Equation. Environmental Science \& Technology January 1: 17-23.

9 Prüss-Üstün A, Bos R, Gore F, Bartram J (2008) Safer water, better health: costs, benefits and sustainability of interventions to protect and promote health. Geneva: World Health Organization.

10 United Nations (2005) UNICEF Water, Sanitation and Hygiene Strategies for 2006-2015. New York: United Nations (UN).

11 United Nations (2010) Resolution 64-292: The human right to water and sanitation. United Nations (UN).

12 Lancet (2014) Water and sanitation: addressing inequalities. Lancet 383: 1359.

13 United Nations (2005) UNICEF Water, Sanitation and Hygiene Strategies for 2006-2015. 
that, although significant progress had been made, evidence suggested that achievements had often not reached those who were mostly in need ${ }^{14}$. The 2015 UN Report confirmed precisely that: uneven achievements are a challenge for the next era of development ${ }^{15}$. The world has met the access to safe drinking-water target, albeit with uneven progress across regions and socioeconomic groups. The target to improve access to basic sanitation, however, was not met: despite improvement, in 2015 about 2.4 billion had no access to improved sanitation (946 million still practicing open defecation $)^{16}$. The conclusion is straightforward: if human rights efforts should focus on the worst off populations, inequality in access should be a major concern.

In Brazil, the official report to the UN stated that target $\mathrm{C}$ of MDG was met both in what concerns access to water and to sanitation ${ }^{17}$. There is no controversy around the access to water, but a nongovernmental analysis may have a different assessment on improved sanitation. Researchers considered not likely that target $\mathrm{C}$ would be met with regards to sanitation. ${ }^{18}$

Leaving the MDG discussion aside and considering more broadly the available data on sanitation services in Brazil (here defined as sewage collection and treatment), in 2001, 45.4\% of the households had access to sanitation services. In 2013 , the figure increased to $58.2 \%$. The households with access to sanitation are concentrated in some cities: according to the 2010 Population Census, only $28.5 \%$ of Brazilian municipalities had sewage treatment systems, and sewage collection systems were available in only $55.2 \%$ of municipalities. ${ }^{19}$

Although this increase in access to sanitation had important environmental and health impacts ${ }^{20}$, marked regional and socioeconomic

New York: United Nations (UN).

14 UNICEF (2010) Social Protection: Accelerating the MDGs with Equity. UNICEF.

15 United Nations (2015) The Millennium Development Goals Report. New York: United Nations.

16 WHO (2014) Millennium Development Goals (MDGs). Fact sheet №290. Updated May 2014. World Health Organization. http://www.who.int/mediacentre/factsheets/fs290/en/ Assessed Oct 8, 2014.

17 IPEA (2014) Objetivos de Desenvolvimento do Milênio: Relatório Nacional de Acompanhamento. Brasília: Instituto de Pesquisa Econômica Aplicada, Secretaria de Planejamento e Investimentos Estratégicos. 208 p.

18 Neri M, Osório R (2014) V National Monitoring Report on the Millennium Development Goals. Brasilia: Brasil - Secretaria de Assuntos Estratégicos (SAE/PR). http://www.sae.gov.br/ site/wp-content/uploads/Release-ODM-English-Final.pdf. Assessed September, 2014.

19 IBGE (2011) Atlas de Saneamento 2011. Rio de Janeiro: Instituto Brasileiro de Geografia e Estatística - IBGE.

20 Barreto ML, Genser B, Strina A, Teixeira MG, Assis AMO, et al. (2007) Effect of citywide sanitation programme on reduction in rate of childhood diarrhoea in northeast Brazil: assessment by two cohort studies. Lancet 370: 1622-1628. 
inequalities in access are observed, with the northern portion of the country and poor people lacking the proper facilities, mirroring inequalities observed in other social and health-related indicators ${ }^{21}$.

The cost to achieve complete coverage of access was estimated in 2013 at $7.4 \%$ of the national gross domestic product (GDP). ${ }^{22}$ And evidence suggests that economic development per se will not overcome the sanitation deficit nor increase access in the most needed areas in the short run; instead, it can make the sanitation deficit and the inequality even worse over time ${ }^{23}$. Empirical studies have accessed that hypothesis in light of Kuznets theory that suggests an inverted U-shape for the relationship between economic development and inequality ${ }^{24}$.

From a legal perspective, Brazilian Law qualifies sanitation as a public service since 1970's and the 1988 Brazilian Constitution stated a duty of all levels of Government to improve sanitation conditions. Municipalities are in charge of delivering the services, although States can also be involved in metropolitan areas. Federal Government is in charge of establishing national guidelines for sanitation, technical and financial support.

Privatization has been taking place since the late 1990's and according to 2014 data, 297 municipalities had decided to privatize to some extent the delivery of sanitation services. ${ }^{25}$ The experience is still being assessed from multiple perspectives, but in regards to the quality of the service, the evidence so far suggests no differences between

21 Mejia A, Azevedo LGT, Gambrill MP, Baltar AM, Triche T (2003) Água, redução de pobreza e desenvolvimento sustentável. Brasília: Banco Mundial. Saiani CCS, Junior RT (2010) Evolução do acesso a serviços de saneamento básico no Brasil (1970 a 2004). Economia e Sociedade Campinas 19: 79-106.

22 Trata Brasil (2014) Benefícios econômicos da espansão do saneamento no Estado de Rondônia. Porto Velho, RO: Trata Brasil; Exante.

23 Saiani CCS, Junior RT, Dourado JA (2013) Déficit de acesso a serviços de saneamento ambiental: evidências de uma Curva Ambiental de Kuznets para o caso dos municípios brasileiros? Economia e Sociedade Campinas 22: 791-824. Victora CG, Vaughan JP, Barros FC, Silva AC, Tomasi E (2000) Explaining trends in inequities: evidence from Brazilian child health studies. Lancet Vol 356: 1093-1098.

24 IPEA (2014) Objetivos de Desenvolvimento do Milênio: Relatório Nacional de Acompanhamento. Brasília: Instituto de Pesquisa Econômica Aplicada, Secretaria de Planejamento e Investimentos Estratégicos. 208 p. Saiani CCS, Junior RT, Dourado JA (2013) Déficit de acesso a serviços de saneamento ambiental: evidências de uma Curva Ambiental de Kuznets para o caso dos municípios brasileiros? Economia e Sociedade Campinas 22: 791-824. 25 ABCON, SINDCON (2014) Panorama da Participação Privada no saneamento Brasil - 2014. ABCON (Associação Brasileira das Concessionárias Privadas de Serviços Públicos de Água e Esgoto), SINDCON (Sindicato Nacional das Concessionárias Privadas de Serviços Públicos de Água e Esgoto). http://abconsindcon.com.br/wp-content/uploads/2014/05/Panorama-dainiciativa-Privada-do-Setor-Saneamento-Brasil-2014.pdf. Assessed May, 2015. 
services provided by public and private entities. ${ }^{26}$

Notwithstanding its significance for health and for other rights, sanitation still struggles to be regarded as a political priority for Governments in democracies like Brazil. It is only natural that decisions about where to invest limited resources will consider also, and sometimes mainly, the political criteria of the electoral return each choice can provide to public officials. Sanitation policies, although very cost-effective in the long run, are more connected with prevention not with the cure of an actual disease -, and require long time and continuous investments to be implemented, in such a way the benefits they produce are not as clearly perceived by the population as the ones associated with pharmaceutics. Furthermore, Brazilian law requires minimum investments in the public health system by all three levels of Government (Federal, State and Municipal), but expenses on sanitations services cannot be included under this item of expenditure.

Therefore, and despite the need to bridge the gap in access to sanitation, public expenditure makes up a consistently low percentage of GDP, ranging from $0.13 \%$ in 1996 to $0.09 \%$ in 2005 , and the percentage of the total federal expenses applied to sanitation investments varied from $0.31 \%$ in 1994 to $0.15 \%$ in $2005^{27}$. In 2010 , for instance, the Brazilian Ministry of Health spent $45.93 \%$ of its budget in specialized hospital care, $8.82 \%$ in pharmaceutics, and only $2.13 \%$ in sanitation initiatives ${ }^{28}$. It seems that there are low political incentives for governments to prioritize sanitation policies.

At the same time, poor people suffer more without sanitation services than the better off and usually have less capacity to be heard in the political arena, as they lack the necessary time, information and ability to organize in order to effectively influence public officials. The inequality, tough, hits twice. Not only the groups in need of sanitation services will face more difficulties to get them from the political dispute, but the more politically articulated groups - that already enjoy sanitation services - will mostly likely advocate public resources to be invested in other services, not on sanitation.

Brazilian Law does not describe sanitation services as a right, but

26 IBGE (2014) Síntese de Indicadores Sociais. Uma análise das condições de vida da população brasileira. Rio de Janeiro: Instituto Brasileiro de Geografia e Estatística - IBGE. Cardoso AM, Santos RV, Coimbra Jr. CEA (2005) Mortalidade infantil segundo raça/cor no Brasil: o que dizem os sistemas nacionais de informação? Cadernos de Saude Publica 21: 1602-1608

27 RIPSA (2008) Indicadores básicos para a saúde no Brasil: conceitos e aplicações. Brasilia: Rede Interagencial de Informação para a Saúde (RIPSA), Ministério da Saúde; Organização Pan-Americana da Saúde. available at http:/www.sae.gov.br/site/wp-content/uploads/ReleaseODM-English-Final.pdf

28 IPEA (2012) Políticas sociais: acompanhamento e análise. Brasília Instituto de Pesquisa Econômica Aplicada, Diretoria de Estudos e Políticas Sociais. 
Courts construe sanitation rights enforceability from the duty imposed upon the Government and also from rights the Constitution provides for as access to health, housing and environmental rights. Public interest litigation could help at least as a tool to help set the political agenda in this scenario.

\section{HuMAN RightS LITIGATION AND INEQUALITY}

Framing a claim as a human right, or as a right more broadly, may allow the use of legal apparatus to have it adjudicated and enforced, which include Court proceedings and orders. However, when the defendant is the government and adjudication involves tax payers' money, human rights litigation can raise specific concerns on the inequality effects it may trigger. The main reason for these concerns is simple: going to Courts also requires time, money and information, and it is not an option easily available for the most disenfranchised in societies. Therefore, better-off groups are the ones who most file lawsuits and benefit from them, using the human rights grammar in Courts. ${ }^{29}$

This critique has been particularly directed toward conventional health rights litigation: lawsuits asking for pharmaceuticals and medical procedures. The criticism is that health rights litigation promotes inequality because it concentrates resources in a small number of plaintiffs and because plaintiffs usually are not from the worst-off groups within the population. This would mean not only that plaintiffs get more from the health system than the rest of the population, but also that the worst-off are, after all, paying that bill.

As already mentioned, disenfranchised people in developing countries usually have fewer means to be heard in the political arena. For similar reasons (limitations on time, money, information and ability to organize), poor people face many more hurdles to suing for their rights, and it is unlikely they will surmount them.

But what about public interest litigation? Would this kind of criticism apply the same way? Hypothetically, public interest litigators would be in a better position to reach those most in need and use the legal apparatus to benefit them. So, it is possible that this general criticism to litigation does not apply particularly to public interest litigation.

Moreover, countries have different standing rules for filing public interest lawsuits and this feature can make a difference in the inequality discussion. In some places, lawsuits may only be filed by people who will be directly impacted by the court decision, while in other countries those rules are more flexible and third parties can file on behalf of needy populations. Usually these third parties - NGOs, public

29 Bilchitz D (2007) Poverty and fundamental rights: the justification and enforcement of socio-economic rights. Oxford; New York: Oxford University Press. xviii, 279 p. 
defenders, etc. - are free to qualify a population as needy and to choose what kind of claim they are going to pursue in court. Although free to choose the aim of their efforts, these individuals could (and should) establish an agenda of litigation on behalf of the poor.

When it comes to sanitation, the legal framework in place in Brazil does not allow individual home owners to claim for sanitation services in Courts. However, Public Lawyers, Environmental Agencies, and Public Prosecutors are allowed to file lawsuits, and ask for sanitation services that should be provided by municipalities and/or States. The odds of better-off home owners going to Courts are reduced in this environment, therefore the inequality criticism may not be so relevant here. Anyway, better-off home owners probably don't need to use Courts for that, because they already enjoy sanitation services.

The hypothesis that public interest litigators could help poor people's needs to be heard by the judicial system and by society should be stronger in Brazil also because of the existence of the Public Prosecutors Office, an institution unique to the Brazilian legal system that has the main goal of protecting the public interest mostly through litigation. ${ }^{30}$ Public interest includes actions in several areas, such as criminal prosecution, environment and other diffuse and collective interests, rights of Indigenous populations, and human rights related to issues such as health, education, and housing. Public Prosecutors are functionally independent, and thus it is common that they file lawsuits against the government, despite being a public institution. While not all municipalities have a Public Prosecutor's Office (about half of the municipalities do have an office), each branch acts on a defined catchment area that includes a set number of municipalities in order to provide full geographical coverage.

But what does the data can tell about this hypothesis? Is public interest litigation on sanitation rights in Brazil really prioritizing the poor?

\section{Public Interest Litigation and inequality: the case on SANITATION IN BRAZIL}

Previous research has shown that from January 2003 to March 2013, at least 258 court orders (court orders were used as a proxy measure of lawsuits, since there is no database of lawsuits filed) were issued addressing sanitation rights, and $85 \%$ of those were filed by Public Prosecutors. These court orders referred to lawsuits filed from 1990 to 2012. The requests may encompass different provisions, such as the expansion of the sewage collection systems for a neighborhood,

30 Brasil (1988) Constituição Federal de 1988 (updated version: 2014). Brasilia. Available at http://www2.camara.leg.br/atividade-legislativa/legislacao/Constituicoes_Brasileiras/ constituicao1988.html/ConstituicaoTextoAtualizado_EC82.pdf. 
or the construction of a sewage treatment plant for public buildings or for a whole city, among others. Courts have granted $77 \%$ of these requests; the other $23 \%$ of the requests were initially not granted but plaintiffs can file an appeal. ${ }^{31}$ Of the granted requests, $4 \%$ have already been fully implemented (meaning that the sanitation construction has been finalized). The implementation of this kind of court order takes time, and it can take up to 20 years depending on the complexity of the project $^{32}$, requiring active monitoring effort from Public Prosecutors. Enforcement is still taking place in the remaining of cases, albeit in a clumsily way sometimes. Nevertheless, results from Court orders have been documented. For example, in 2014, to comply with a court order from 2011, the construction of a plan to provide sewage collection and treatment for Barra do Sul, a municipality in the southern state of Santa Catarina was initiated benefiting 8,500 people. Also, a state prison (with about 2,500 inmates) located in the northern state of Amapa was equipped with a system to treat and adequately discharge its sewage as a result of a court order.

In 2010 , less than half of the households in $71 \%$ of the 5,565 Brazilian municipalities had access to sanitation ${ }^{33}$. Considering the very small number of court orders (only 258) addressing the issue, one could question if the Courts are playing an important role in improving the sanitation conditions of those municipalities with most precarious access to sanitation. When and where judicial interventions occurred and whom they benefited depend mostly on the public law litigators' priorities and on their comprehensive knowledge of local needs. While it is unreasonable to expect that the Public Prosecutors Office can solve the sanitation gap in Brazil, this legal mechanism does provide a unique opportunity to areas traditionally burdened by social inequalities to fulfill their rights to basic services. The extent to which the Public Prosecutors Office is indeed contributing to reduce inequalities in access to sanitation at the municipal level in Brazil is currently unknown.

This paper addresses those issues and evaluates if there is a direct connection between sanitation needs and litigation through the Public Prosecutors Office in Brazil. We assembled data from Population Censuses regarding access to sanitation by municipality, in order to identify areas most in need for services, and to assess the extent to

31 Barcellos APd (2014) Sanitation Rights, Public Law Litigation, and Inequality: A Case Study from Brazil. Health and Human Rights 16.

32 Brasil (2012) Termo de Referência para elaboração de planos municipais de saneamento básico. Procedimentos relativos ao convênio de cooperação técnica e financeira da Fundação Nacional de Saúde. Brasília: Fundação Nacional de Saúde (FUNASA), Ministério da Saúde (MS).

33 IBGE (2011) Atlas de Saneamento 2011. Rio de Janeiro: Instituto Brasileiro de Geografia e Estatística - IBGE. 
which court orders were issued in those areas. All information was geocoded in order to assess the existence of regional differences.

Our results showed that based on the court orders that were issued (positive or negative) there is no indication that lawsuits were filed in municipalities with the largest sanitation gap, highlighting a rarely discussed subject: the priority targets elected by public law litigators and how they decide over them. This is particularly important to Public Prosecutors in Brazil, as they are public officials, publicly funded to promote human rights, and thus should follow an informed and accountable process of setting priorities. Our analysis points out to the need of establishing protocols for priority setting, and of increasing the visibility of the Public Prosecutor's role to the population as a way to empower communities.

\section{Methods}

\section{Data sources}

Data utilized in this analysis were obtained from multiple sources, and were aggregated at the municipal level - until 2010 there were 5,565 municipalities distributed across 26 states and one federal district (Brasília, the capital), and 5 regions. Data on court orders issued from January 2003 to March 2013 and the respective year when the lawsuits were filed were extracted from the website of each State and Federal Court of Appeals, with the exception of two states that did not have online data for the period analyzed. In the cases when the date of filing the lawsuit was not available, it was estimated that filing took place 18 months prior to the time when the first Court order was issued. It is important to emphasize that there is no database that records all lawsuits that have been filled. Therefore, court orders were used as a proxy for the existence of lawsuits. From the websites of the State and Federal Public Prosecutor's Offices we obtained information on the location of branches by municipality in order to appraise if the lack of an office could be a barrier for increasing the visibility of those areas most in need for sanitation.

The data about court orders in Brazil have some limitations. First, two states did not have online records for the 10-year period analyzed, and did not allow access to paper records. Yet, it is unlikely that the profile of sanitation lawsuits from these states would be different from the one here presented (based on the remaining 24 states and the Federal District). Second, the search could not capture information about other activities Public Prosecutors could be carrying out to advance access to sanitation, apart from filing lawsuits (e.g., negotiations with public 
officials). Also, it was not possible to track lawsuits still awaiting a decision, but plaintiffs usually ask for preliminary injunctions, so it only takes some months, after the lawsuit is filed, for a positive or negative decision to be issued.

Information on the percentage of households with access to sewage collection, and on total population was obtained from the 1991, 2000 and 2010 Population Censuses. We included the three censuses to cover the estimated time period when the lawsuits were filed. From the Brazilian Superior Electoral Court we assembled information on the political party governing the municipality, state, and the country, in an attempt to evaluate if municipalities whose mayor was affiliated to the same political party of the state governor could facilitate sanitation rights litigation. Municipal gross domestic product per capita (GDP per capita) was obtained from the Brazilian Institute of Applied Economic Research (IPEA), and is an indicator of the municipality's wealth. We also obtained data on the municipal Human Development Index (HDI), extracted from the Human Development Atlas ${ }^{34}$, as a proxy for the municipality's standard of living. Although the Multidimensional Poverty Index (MPI) would be a better index for that purpose ${ }^{35}$, it was not available at the municipal level for Brazil.

A map of Brazilian municipalities was obtained from the Brazilian Institute of Geography and Statistics - IBGE (http://downloads. ibge.gov.br/downloads_geociencias.htm). All spatial information was projected using WGS 1984 UTM Zone 22S, which is the central longitude Universal Transverse Mercator band in Brazil. Map design and management was conducted in ArcGIS 10.2 (ESRI; Redlands, CA).

\section{Analytical approach}

We began by measuring non-spatial descriptive statistics for all variables. In order to appraise inequality in the access to sanitation we calculated the concentration index ${ }^{36}$, considering the municipality as the unit of analysis, the municipal Gross Domestic Product (GDP) as an

34 UNDP, IPEA, FJP (2013) Atlas of Human Development in Brazil 2013. United Nations Development Programme (UNDP), Brazilian Applied Economic Research Institute (IPEA), João Pinheiro Foundation (FJP). http://www.atlasbrasil.org.br/2013/en/home/. Assessed January, 2014.

35 Akire S, Santos. M (2010) Acute Multidimensional Poverty: A New Index for Developing Countries New York: UNDP-HDRO.

36 Wagstaff A (2000) Socioeconomic inequalities in child mortality: comparisons across nine developing countries. Bulletin of the World Health Organization 78: 19-29. Wagstaff A, Paci P, van Doorslaer E (1991) On the measurement of inequalities in health. Social Science and Medicine 33: 545-557. 
income-related indicator, and the number of households with access to sanitation as the health variable. The concentration index ranges from -1 to 1 , with a value of -1 indicating that access to sanitation is concentrated amongst poor municipalities (or those with the lowest GDP), and a value of 1 indicating that access to sanitation is concentrated amongst rich municipalities (or those with the highest GDP). All calculations were performed in Excel (Microsoft, Seattle, WA, USA), and STATA v.11 (Stata Corp., College Station, TX, USA).

Spatial patterns in the proportion of households with access to sanitation by municipality was assessed through the use of the Gi*(d) local indicator of spatial association ${ }^{37}$. Considering the varying size of the municipalities in Brazil, a first-order queen contiguity neighborhood definition was utilized and therefore only municipalities sharing borders were considered neighbors. All results were corrected for multiple and dependent tests utilizing the false discovery rate control procedure ${ }^{38}$. Data management was done in Stata 11 (Stata Corp.; College Station, TX, USA), and spatial analyses were conducted in GeoDA ${ }^{39}$.

Boolean operators (e.g., or, and, not) were applied in order to identify overlap (or the lack of thereof) between the 258 court orders and the municipalities that tested significant for clusters of high or low proportion of households with access to sanitation. Additional variables described above were utilized to summarize the overall profile of municipalities targeted and not targeted with court orders, in light of levels of access to sanitation.

\section{Results: The Gap Persists}

Based on Census data, access to sanitation presented inequalities both between and within regions; better access to sanitation was observed in the Southeast region, while the worst coverage was in the North (Table 1).

37 Getis A, Ord KJ (1996) Local Spatial Statistics: An Overview. In: Longley P, Batty M, editors. Spatial Analysis: Modelling in a GIS environment. pp. 261-277.

38 Castro MC, Singer BH (2006) Controlling the false discovery rate: a new application to account for multiple and dependent tests in local statistics of spatial association. Geogr Anal 38: $180-208$.

39 Anselin L, Syabri I, Kho Y (2006) GeoDa: an introduction to spatial data analysis. Geogr Anal 27: 93-115. 
Panor. Braz. law - Vol 4, Nos. 5 and 6 (2016)

Table 1. Access to sanitation and selected indicators by region, Brazil

\begin{tabular}{|c|c|c|c|c|c|c|}
\hline \multirow{2}{*}{ Region } & \multirow{2}{*}{$\begin{array}{c}\text { Year } \\
(*)\end{array}$} & \multicolumn{2}{|c|}{$\begin{array}{l}\% \text { households with } \\
\text { access to sanitation }\end{array}$} & \multirow{2}{*}{$\begin{array}{c}\text { HDI } \\
(\max , \min )\end{array}$} & \multicolumn{2}{|c|}{$\begin{array}{l}\text { Lawsuits with Court Orders } \\
\text { issued in 2003-2013 }\end{array}$} \\
\hline & & Median & $(\max , \min )$ & & Approved & $\begin{array}{l}\text { Denied (under } \\
\text { appeal) }\end{array}$ \\
\hline \multirow{3}{*}{ North } & 1991 & 0 & $(33.29,0)$ & $(0.562,0.138)$ & 2 & 0 \\
\hline & 2000 & 0.16 & $(41.12,0)$ & $(0.654,0.222)$ & 11 & 5 \\
\hline & 2010 & 0.53 & $(45.43,0)$ & $(0.788,0.418)$ & 2 & 0 \\
\hline \multirow{3}{*}{ Northeast } & 1991 & 0 & $(72.24,0)$ & $(0.576,0.120)$ & 2 & 0 \\
\hline & 2000 & 1.43 & $(86.57,0)$ & $(0.694,0.208)$ & 25 & 4 \\
\hline & 2010 & 6.56 & $(91.80,0)$ & $(0.788,0.443)$ & 17 & 5 \\
\hline \multirow{3}{*}{$\begin{array}{l}\text { Center- } \\
\text { West }\end{array}$} & 1991 & 0 & $(73.65,0)$ & $(0.616,0.183)$ & 1 & 0 \\
\hline & 2000 & 0.64 & $(87.36,0)$ & $(0.725,0.373)$ & 8 & 2 \\
\hline & 2010 & 1.33 & $(91.09,0)$ & $(0.824,0.526)$ & 2 & 1 \\
\hline \multirow{3}{*}{ Southeast } & 1991 & 43.68 & $(95.76,0)$ & $(0.697,0.174)$ & 16 & 3 \\
\hline & 2000 & 60.78 & $(99.26,0)$ & $(0.820,0.336)$ & 56 & 15 \\
\hline & 2010 & 70.25 & $(99.76,0)$ & $(0.862,0.529)$ & 14 & 8 \\
\hline \multirow{3}{*}{ South } & 1991 & 0 & $(70.97,0)$ & $(0.681,0.208)$ & 1 & 0 \\
\hline & 2000 & 2.32 & $(83.37,0)$ & $(0.777,0.377)$ & 41 & 12 \\
\hline & 2010 & 4.42 & $(92.59,0)$ & $(0.847,0.546)$ & 1 & 4 \\
\hline
\end{tabular}

$\left.{ }^{*}\right)$ Access to sanitation and HDI were calculated for the year indicated in the column, which refers to the year when the Population Census was conducted. Frequency of lawsuits was computed for time periods (1991-1999, 2000-2009, and 2010-2012).

This regional pattern is also clear in Figure 1. Significant clusters of high access to sanitation were concentrated in the southern portion of the country (with some municipalities consistently showing significant high access to sanitation over all the three census years analyzed), while significant clusters of low access were observed in municipalities located in the northern part. Clustering of sanitation in space was expected, since access to sanitation is correlated with poverty and 
other social and health indicators, and thus often shows geographical variations that resemble the pattern of spatial effects observed for these other indicators.

Figure 1. Clustering pattern of access to sanitation and court orders issued by municipality

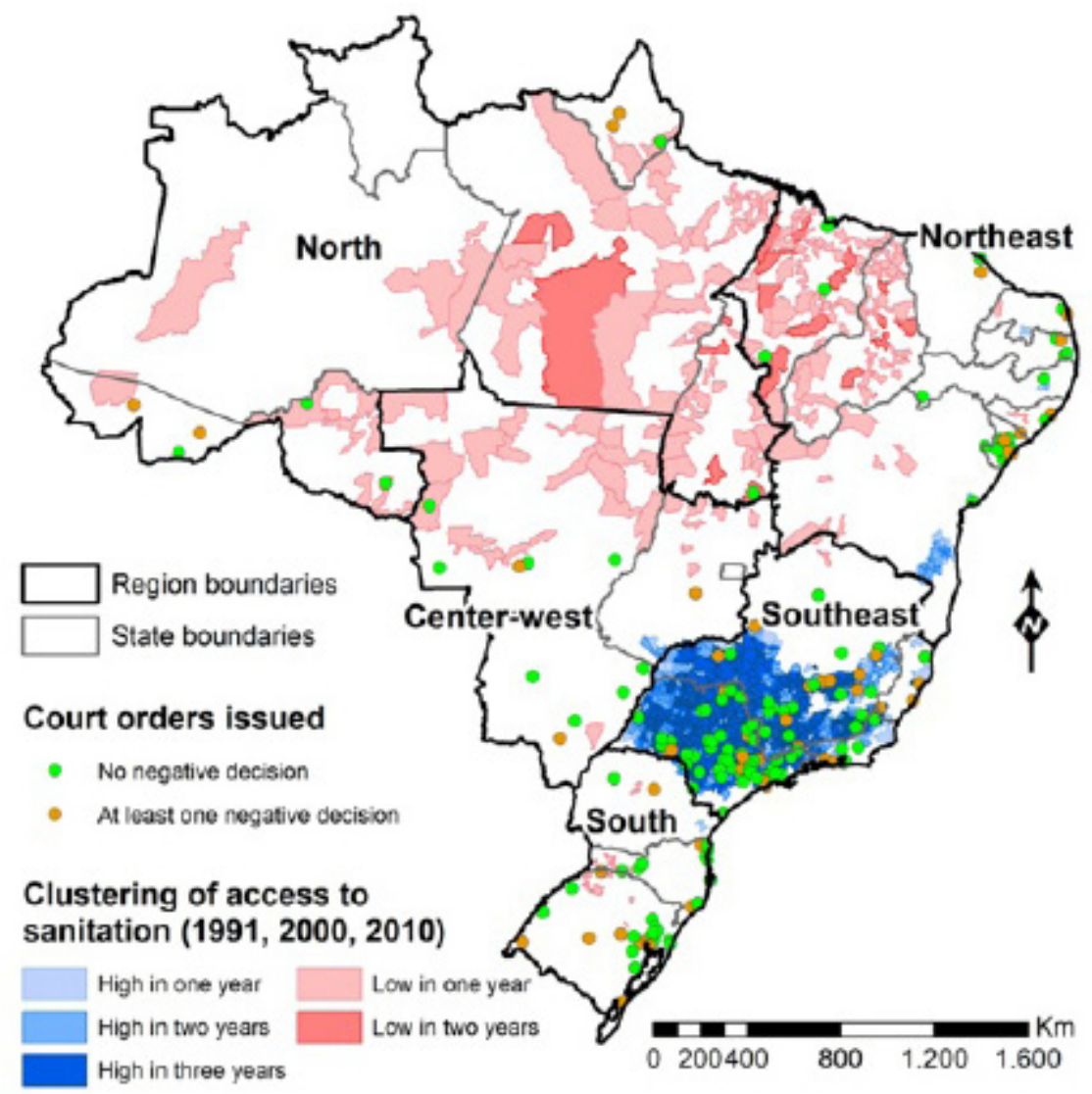

These spatial patterns have their roots in history, political decisions, marginalization of specific population groups, environmental vulnerabilities, and limited financial resources, among others. Indeed, the regional pattern here presented is quite similar to the spatial distribution of the Municipal HDI in Brazill ${ }^{40}$.

40 UNDP, IPEA, FJP (2013) Atlas of Human Development in Brazil 2013. United Nations Development Programme (UNDP), Brazilian Applied Economic Research Institute (IPEA), João Pinheiro Foundation (FJP). http://www.atlasbrasil.org.br/2013/en/home/. Assessed 
The inequality in access across municipalities was corroborated by the concentration index: 0.8958 (standard error $(\mathrm{SE})=0.0087$ ) in $1991,0.8681(\mathrm{SE}=0.0086)$ in 2000 , and $0.8509(\mathrm{SE}=0.0084)$ in 2010 , indicating that (i) there was a large concentration of access to sanitation in municipalities with better GDP; and (ii) the improvements in the provision of sanitation during the past three decades, albeit with positive impacts in people's health, had a marginal contribution to reduce inequalities in access.

Figure 1 also shows the municipalities where court orders were issued and highlights three important issues. First, municipalities that have a historical pattern of low access to improved sanitation were not targeted by public law litigations. Second, and in contrast, municipalities with much better access to sanitation (and higher GDP and HDI) had lawsuits filed for the purpose of enforcing sanitation rights. Third, the distribution of lawsuits reinforces the pattern of regional inequality in Brazil: the South and Southeast regions have more representation, while the North and Northeast regions remain unattended (despite being those most in need).

The 258 court orders issued between 2003 and 2013, covered 180 unique municipalities (143 municipalities had one single court order issued, 22 had 2, 9 had 3, 2 had 5, and 4 municipalities had 6 or more), and $35 \%$ were issued a negative decision, currently under appeal. Roughly a quarter of the court orders in each region were issued a negative decision, with the exception of the Northeast region (17\%) and the South $(27 \%)$. Of note is the fact that no municipality that tested for a significant cluster of low access to sanitation, and for which a lawsuit was filed to claim sanitation rights, was issued a negative decision.

Regionally, of the total court orders $43.4 \%$ were issued in the Southeast region and only $7.6 \%$ in the North, a disparity if one considers where the lack of sanitation facilities is, as shown in Table 1 and Figure 1. In addition, $69.8 \%$ and $73.6 \%$ were issued in municipalities with GDP per capita above the GDP state and national averages, respectively. Considering the significant clusters of access to sanitation, about one third of the court orders were issued in municipalities that significantly tested for a cluster of high access to sanitation, while only 8 court orders were issued in municipalities identified as clusters of low access to sanitation (thus, the majority of court orders were issued in municipalities not significant for clustering). Regarding the presence of a branch of the Public Prosecutor's Office, only $10.5 \%$ of the court orders benefited municipalities that did not have an office. Considering the HDI, $48.5 \%$ of the court orders benefited municipalities with an index below the national HDI. Taken together, these indicators expose

January, 2014. 
a conflict between public law litigation and reduction of the inequality gap in access to sanitation facilities.

With respect to political representation, no evidence was observed regarding a possible coalition of municipal, state, and national representatives from the same political party that could eventually influence the Public Prosecutors' decisions. Of the 258 lawsuits filed from 1990 to 2012, 79\% were observed in municipalities where the mayor and the governor had different political party affiliations, and $92 \%$ in municipalities in which the parties of mayors, governors, and the president of the nation were different.

\section{Discussion}

This paper assessed if sanitation court orders issued from 2003 to 2013 (corresponding to sanitation lawsuits filed from 1990 to 2012), were targeted to municipalities most in need of services. Results showed a disconnect between litigation and demand for sanitation, and indicated that municipalities that were better off in various social and economic indicators were the ones receiving attention, which contributes to further exacerbate regional inequalities.

Our findings raise prioritization issues. One could argue that the presupposition that Public Prosecutors should prioritize the most in need of sanitation services is not sound enough because the lawsuits that were filed did address real needs of the population (intra-municipal inequality in the distribution of resources is also observed, and thus, unless $100 \%$ of the population has access to sanitation, there is room for improvement). However, three questions regarding inequality need to be brought to discussion.

First, Brazilian Law has set a goal of inequality reduction; not only income inequality, but also in access to basic rights (both aspects being connected). Thus, one would expect that Public Prosecutors should guide their actions to these provisions ${ }^{41}$. Notwithstanding, no standard operational protocol exists regarding how prosecutors should become aware of local needs, engage with local communities, and prioritize actions they pursue. International organizations have also been concerned that public policies engaged in the promotion of human rights should prioritize the poor ${ }^{42}$. Second, a human rights approach for sanitation rights suggests that a lexical order must be observed in the initiatives, so that every person should have access to basic services

41 Brasil (1988) Constituição Federal de 1988 (updated version: 2014). Brasilia. Available at http://www2.camara.leg.br/atividade-legislativa/legislacao/Constituicoes_Brasileiras/ constituicao1988.html/ConstituicaoTextoAtualizado_EC82.pdf.

42 Mestrum F, Özden M (2012) The Fight against Poverty and Human Rights. Critical Report no. 11. Geneva: CETIM. 
before some groups receive enhanced services ${ }^{43}$. Third, without a targeted initiative to prioritize their needs, the most marginalized are likely to be the last to benefit from any public policy, as suggested by the inverse equity hypothesis ${ }^{44}$. As noted, the MDGs experience, despite its partial success, confirmed that.

Regarding priority setting criteria, Public Prosecutors Offices are internally organized in teams who concentrate in topics (e.g., criminal prosecution, human rights, and environment). but there is no internal proceeding or general criteria on how to decide what their priorities should be. Public Prosecutors report that they usually act after receiving complaints from society. But there is no public information of all the complaints received, who presented them, which ones have triggered initiatives and why. In addition, even if poor communities lacking basic sanitation services could have correct information about the role of Public Prosecutors and the means to self-organize and bring their complaints, they may be too distant from the nearest Public Prosecutor, and the municipality where they live may lack a branch of the Public Prosecutor's Office, as our results indicated. In other words, the complaint-reacting criteria will probably concentrate the Public Prosecutors activity in other groups' interests, not in those of the most in need, as has been reported to happen with Courts ${ }^{45}$.

Moreover, it is expected that Public Prosecutors visit all municipalities in the catchment area of the Public Prosecutor's Office where they work in order to identify issues that could benefit the community through litigation. However, the diversity of topics which the office oversees - criminal prosecution, children's rights, elderly rights, Indigenous rights, human rights in general, environmental, etc. could result in passive actions. Without a standard protocol on priority setting, prosecutors are probably only able to respond to demands that are brought to their attention by individuals or community groups. This possibility, coupled with the fact that those most in need may not be empowered to claim for their rights (and may live in municipalities without a Public Prosecutor's Office) would contribute to the reduced number of lawsuits in the most underserved areas.

43 United Nations (1966) International Covenant on Economic, Social and Cultural Rights. 44 Victora CG, Vaughan JP, Barros FC, Silva AC, Tomasi E (2000) Explaining trends in inequities: evidence from Brazilian child health studies. Lancet Vol 356: 1093-1098.

45 Chieffi AL, Barata RB (2009) Judicialização da política pública de assistência farmacêutica e eqüidade. Cad Saúde Pública, Rio de Janeiro 25: 1839-1849. Silva VA, Terrazas FV (2011) Claiming the Right to Health in Brazilian Courts: The Exclusion of the Already Excluded? Law \& Social Inquiry 36: 825-853. Ferraz OLM (2009) The right to health in the courts of Brazil: worsening health inequities? Health and Human Rights 11: 33-45. Ferraz OLM, Vieira FS (2009) Direito à Saúde, Recursos Escassos e Equidade: Os Riscos da Interpretação Judicial Dominante. DADOS - Revista de Ciências Sociais, Rio de Janeiro 52: 223-251. 
In addition, to guarantee transparency of the process, information systems should be put in place facilitating the issuing, on a regular basis, of reports summarizing: lawsuits filed by area, what/who originated the complaint, and time between filing and implementation, among other variables. Such reports should follow the transparency policy implemented by the Brazilian government in 2011 (Federal Law 12.527) and be made publicly available. Also, through cooperation with institutions that produce and/or have access to information (e.g., universities, non-governmental organizations, and public agencies), Public Prosecutors could be better informed regarding local needs, and thus better equipped to set priorities. For example, data used in this paper were collected by Brazilian public agencies and are freely available to anyone through institutional websites. The proposed information systems combined with socio-demographic and economic data would allow a comprehensive analysis of the role played by the Public Prosecutors Office in protecting the public interest.

\section{Conclusions}

Although public law litigation can be a tool to address inequalities in access to rights, this paper has shown that efforts of Brazilian Public Prosecutors to seek the promotion of sanitation rights are mostly concentrated in areas with already higher access to sanitation. Albeit with positive impacts, these actions fail to target areas most in need and thus do not contribute to reduce the sanitation gap. These results suggest the need for an open debate regarding three important issues: (i) the possibility of establishing priority setting guidelines for Public Prosecutors, (ii) the demand for an integrated information system that promotes transparency of the activities of the Public Prosecutors Office, and (iii) the need to create effective mechanisms that allow Public Prosecutors to reach out (on a regular basis) to communities they serve.

Although the Public Prosecutor Office is an institution unique to Brazil, some of the ideas discussed above could be useful for public law litigation in other developing countries. If institutional public interest litigators (mostly non-governmental organizations) are located in the central areas of major cities and work with the complaint-reacting logic, as is usually the case, they probably are facing (and will continue to face) similar hurdles trying to prioritize their efforts to reach disadvantaged populations and to get Court orders enforced. 


\section{REFERENCES}

ABCON, SINDCON. Panorama da Participação Privada no saneamento Brasil - 2014.

ABCON (Associação Brasileira das Concessionárias Privadas de Serviços Públicos de Água e Esgoto), SINDCON (Sindicato Nacional das Concessionárias Privadas de Serviços Públicos de Água e Esgoto). Available at. $<$ http://abconsindcon.com.br/wp-content/uploads/2014/05/ Panorama-da-iniciativa-Privada-do-Setor-Saneamento-Brasil-2014. pdf $>$. Assessed May, 2015.

AKIRE S, Santos, M. Acute Multidimensional Poverty: A New Index for Developing Countries New York: UNDP-HDRO, 2010.

ANSELIN L, Syabri I, Kho Y. GeoDa: an introduction to spatial data analysis. Geogr Anal, 27: 93-115, 2006.

BARCELLOS APd. Sanitation Rights, Public Law Litigation, and Inequality: A Case Study from Brazil. Health and Human Rights 16, 2014.

BARRETO, ML, Genser B, Strina A, Teixeira MG, Assis AMO, et al. Effect of city-wide sanitation programme on reduction in rate of childhood diarrhoea in northeast Brazil: assessment by two cohort studies. Lancet 370: 1622-1628, 2007.

BILCHITZ, D. Poverty and fundamental rights: the justification and enforcement of socio-economic rights. Oxford; New York: Oxford University Press. xviii, 2007, 279 p.

BRASIL. Constituição Federal de 1988 (updated version: 2014). Brasilia. Available at http://www2.camara.leg.br/atividade-legislativa/ legislacao/Constituicoes_Brasileiras/constituicao1988.html/ ConstituicaoTextoAtualizado_EC82.pdf.

BRASIL. Termo de Referência para elaboração de planos municipais de saneamento básico. Procedimentos relativos ao convênio de cooperação técnica e financeira da Fundação Nacional de Saúde. Brasília: Fundação Nacional de Saúde (FUNASA), Ministério da Saúde (MS), 2012.

CASTRO, MC, SINGER, BH. Controlling the false discovery rate: a new application to account for multiple and dependent tests in local statistics of spatial association. Geogr Anal 38: 180-208, 2006.

CASTRO, MC. Spatio-temporal trends of infant mortality in Brazil. XXVI IUSSP International Population Conference. Marrakech, Morocco, 2009.

CHIEFFI AL, Barata RB. Judicialização da política pública de 
assistência farmacêutica e eqüidade. Cad Saúde Pública, Rio de Janeiro 25: 1839-1849, 2009.

HOFFMANN, R. Mensuração da desigualdade e da pobreza no Brasil. In: Henriques $\mathrm{R}$, editor. Desigualdade e pobreza no Brasil. Rio de Janeiro: IPEA. pp. 81-107, 2000.

MEDICI, AC, AGUNE, AC. Desigualdades sociais e desenvolvimento no Brasil: uma análise dos anos 80 ao nível regional. Ensaios, FEE, Porto Alegre 15: 458-488, 1994.

IPEA. Políticas sociais: acompanhamento e análise. Brasília Instituto de Pesquisa Econômica Aplicada, Diretoria de Estudos e Políticas Sociais, 2014.

IBGE. Síntese de Indicadores Sociais. Uma análise das condições de vida da população brasileira. Rio de Janeiro: Instituto Brasileiro de Geografia e Estatística - IBGE, 2014.

CARDOSO, AM, SANTOS, RV, COIMBRA Jr., CEA. Mortalidade infantil segundo raça/cor no Brasil: o que dizem os sistemas nacionais de informação? Cadernos de Saude Publica 21: 1602-1608, 2005.

FERRAZ, OLM, VIEIRA, FS. Direito à Saúde, Recursos Escassos e Equidade: Os Riscos da Interpretação Judicial Dominante. DADOS Revista de Ciências Sociais, Rio de Janeiro 52: 223-251, 2009.

FERRAZ, OLM. The right to health in the courts of Brazil: worsening health inequities? Health and Human Rights 11: 33-45, 2009.

FEWTRELL， L，KAUFMANN，RB，KAY D，ENANORIA，W, HALLER, L, et al. Water, sanitation, and hygiene interventions to reduce diarrhoea in less developed countries: a systematic review and meta-analysis. The Lancet Infectious Diseases 5: 42-52, 2005.

GETIS, A, ORD, KJ. Local Spatial Statistics: An Overview. In: Longley P, Batty M, editors. Spatial Analysis: Modelling in a GIS environment. pp. 261-277, 1996.

IBGE. Atlas de Saneamento 2011. Rio de Janeiro: Instituto Brasileiro de Geografia e Estatística - IBGE, 2011.

IPEA. Objetivos de Desenvolvimento do Milênio: Relatório Nacional de Acompanhamento. Brasília: Instituto de Pesquisa Econômica Aplicada, Secretaria de Planejamento e Investimentos Estratégicos, 2014, 208 p.

LANCET. Water and sanitation: addressing inequalities. Lancet 383: 1359, 2014.

MEJIA, A, AZEVEDO, LGT, GAMBRILL, MP, BALTAR, AM, TRICHE, T. Água, redução de pobreza e desenvolvimento sustentável. Brasília: Banco Mundial, 2003. 
MESTRUM, F, ÖZDEN, M. The Fight against Poverty and Human Rights. Critical Report no. 11. Geneva: CETIM, 2012.

MONTGOMERY, M, ELIMELECH, M. Water and Sanitation in Developing Countries: Including Health in the Equation. Environmental Science \& Technology January 1: 17-23, 2007.

NERI, M, OSÓRIO, R. V National Monitoring Report on the Millennium Development Goals. Brasilia: Brasil - Secretaria de Assuntos Estratégicos (SAE/PR). http://www.sae.gov.br/site/wpcontent/uploads/Release-ODM-English-Final.pdf. Assessed September, 2014.

PRÜSS-ÜSTÜN, A, BOS, R, GORE, F, BARTRAM, J. Safer water, better health: costs, benefits and sustainability of interventions to protect and promote health. Geneva: World Health Organization, 2008.

RIPSA. Indicadores básicos para a saúde no Brasil: conceitos e aplicações. Brasilia: Rede Interagencial de Informação para a Saúde (RIPSA), Ministério da Saúde; Organização Pan-Americana da Saúde, 2008. Available at <http://www.sae.gov.br/site/wp-content/uploads/ Release-ODM-English-Final.pdf $>$

ROCHA, S. Desigualdade Regional e Pobreza no Brasil: A Evolução 198/95 - Texto para discussão n 567. Rio de Janeiro: IPEA, 1998.

SAIANI, CCS, JUNIOR, RT. Evolução do acesso a serviços de saneamento básico no Brasil (1970 a 2004). Economia e Sociedade Campinas 19: 79-106, 2010.

SAIANI, CCS, JUNIOR, RT, DOURADO, JA. Déficit de acesso a serviços de saneamento ambiental: evidências de uma Curva Ambiental de Kuznets para o caso dos municípios brasileiros? Economia e Sociedade Campinas 22: 791-824, 2013.

SAIANI, CCS, GALVÃO, GC. Evolução das Desigualdades Regionais do Déficit de Acesso a Serviços de Saneamento Básico no Brasil: Evidências de um Incentivo Adverso dos Objetivos de Desenvolvimento do Milênio? 39 ${ }^{\circ}$ Encontro Nacional de Economia Foz do Iguaçu, Paraná: ANPEC, 2011.

SILVA, VA, TERRAZAS, FV. Claiming the Right to Health in Brazilian Courts: The Exclusion of the Already Excluded? Law \& Social Inquiry 36: 825-853, 2011.

TRATADO DO BRASIL. Benefícios econômicos da espansão do saneamento no Estado de Rondônia. Porto Velho, RO: Trata Brasil; Exante WHO (2014) Millennium Development Goals (MDGs). Fact sheet $\mathrm{N}^{\circ} 290$. Updated May 2014. World Health Organization, 2014. Available at <http://www.who.int/mediacentre/factsheets/fs290/en/>, 
Assessed Oct 8, 2014.

UNDP. IPEA. FJP. Atlas of Human Development in Brazil 2013. United Nations Development Programme (UNDP), Brazilian Applied Economic Research Institute (IPEA), João Pinheiro Foundation (FJP), 2013. Available at. <http://www.atlasbrasil.org.br/2013/en/home/>. Assessed January, 2014.

UNICEF. Social Protection: Accelerating the MDGs with Equity. UNICEF, 2010.

UNITED NATIONS. International Covenant on Economic, Social and Cultural Rights, 1996.

UNITED NATIONS. UNICEF. Water, Sanitation and Hygiene Strategies for 2006-2015. New York: United Nations (UN), 2005.

UNITED NATIONS. Resolution 64-292: The human right to water and sanitation. United Nations (UN), 2010.

UNITED NATIONS. The Millennium Development Goals Report. New York: United Nations, 2015.

VICTORA, CG, VAUGHAN, JP, BARROS, FC, SILVA, AC, TOMASI, E. Explaining trends in inequities: evidence from Brazilian child health studies. Lancet Vol 356: 1093-1098, 2000.

WAGSTAFF, A. Socioeconomic inequalities in child mortality: comparisons across nine developing countries. Bulletin of the World Health Organization 78: 19-29, 2000.

WAGSTAFF A, Paci P, DOORSLAER, E van. On the measurement of inequalities in health. Social Science and Medicine 33: 545-557, 1991. 